\title{
Priorities for adolescent girls' education
}

Cynthia B. Lloyd

Population Council

Follow this and additional works at: https://knowledgecommons.popcouncil.org/departments_sbsr-pgy

Part of the Family, Life Course, and Society Commons, Gender and Sexuality Commons, Gender Equity in Education Commons, and the International Public Health Commons How does access to this work benefit you? Let us know!

\section{Recommended Citation}

Lloyd, Cynthia B. 2012. "Priorities for adolescent girls' education," GIRLS FIRST! Perspectives on GirlCentered Programming. New York: Population Council. 
A GIRLS FIRST! PUBLICATION

PRIORITIES FOR ADOLESCENT

GIRLS'

EDUCATION

\section{BY CYNTHIA B. LLOYD}
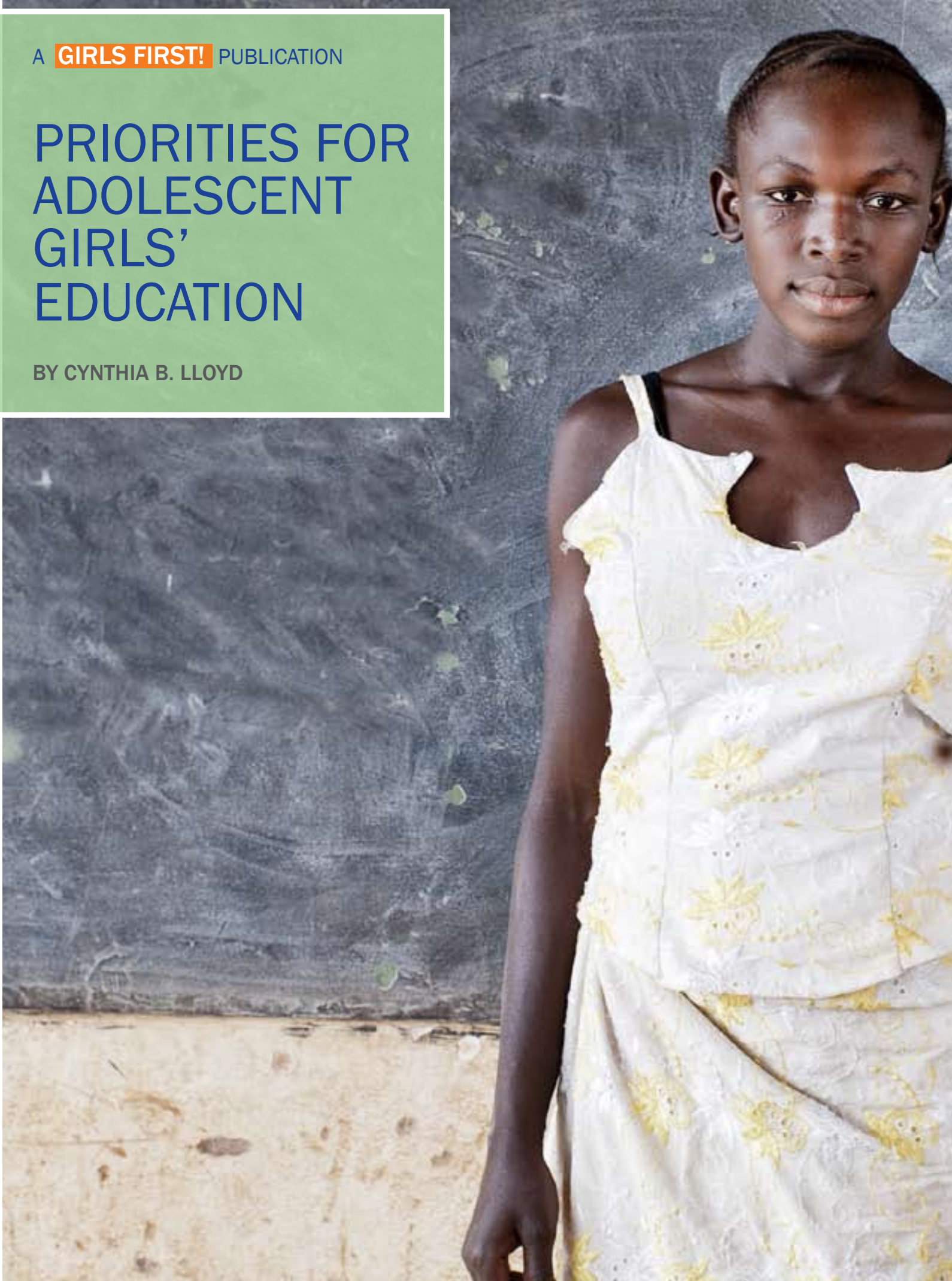

POLICY/

PROGRAMIMING

REVIEW

$3=-8+2 \div-6$ 


\section{GIRLS FIRST!}

\section{PERSPECTIVES ON GIRL-CENTERED PROGRAMMING}

The field of research and programs for adolescent girls has traditionally focused on sexuality, reproductive health, and behavior, neglecting the broader social and economic issues that underpin adolescent girls' human rights, overall development, health, and well-being. Further, efforts to improve girls' lives often spotlight those who control or influence their lives-parents, in-laws, boys, men, perpetrators-overlooking girls themselves.

GIRLS FIRST! Perspectives on Girl-Centered Programming is a set of five thematic Reviews, written by experts at the Population Council. They are snapshots of the knowledge base at a particular moment in this quickly changing field. They address the five strategic priorities defined in the UN Joint Statement, "Accelerating Efforts to Advance the Rights of Adolescent Girls" (March 2010), which represents the collective commitment of seven UN agencies to support governments and partners in advancing key policies and programs for the hardest-toreach adolescent girls. The Reviews therefore:

1. Explore where to go next with education for girls;

2. Outline innovative approaches to improving girls' health;

3. Reframe the field's approach to violence against girls;

4. Describe the best ways to cultivate girl leaders; and

5. Explain novel ways to collect and use data on adolescent girls.

The Reviews put forward innovative arguments for investing in girls and highlight promising practices. They express a forward-looking and evidence-based point of view on where the field must allocate resources in order to most quickly and effectively improve girls' lives.

These Reviews-while written by experts at the Population Council, an organization that has pioneered cutting-edge research and programming for vulnerable and marginalized adolescent girls-were catalyzed with leadership support from the UN Adolescent Girls Task Force. Additional moral and material support was provided by the Nike Foundation, the UN Foundation, and the David and Lucile Packard Foundation. These Reviews add to other programmatic guidance and tool kits now available and serve as an essential reference for anyone seeking to develop successful and sustainable policies and programs for girls. We hope that they will inspire innovative approaches in efforts that realize the rights of marginalized adolescent girls worldwide.

December 2011

Population Council and UN Adolescent Girls Task Force

Disclaimer

The Reviews on programming for adolescent girls in the areas of Education, Health, Reduction of Violence, Girls Leadership, and Data have been prepared by the Population Council for the UN Adolescent Girls Task Force (UN AGTF), with support from the United Nations Foundation, the Nike Foundation, the Packard Foundation.

The views expressed in these Reviews are solely those of the authors and do not necessarily reflect the views of their donor partners. 


\title{
PRIORITIES FOR \\ ADOLESCENT GIRLS' \\ EDUCATION
}

\author{
BY CYNTHIA B. LLOYD
}

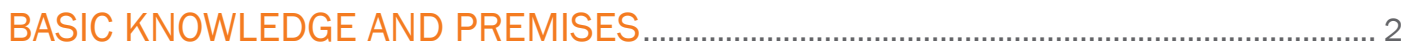

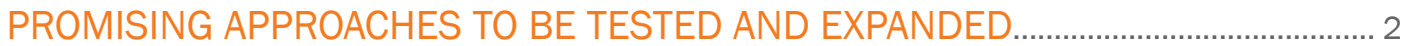

Nonformal educational programs for out-of-school adolescent girls .............................................. 2

Establish and strengthen pathways from nonformal to formal schooling;

focus on younger girls.

Expand support for nonformal educational alternatives with the goal of providing marketable skills.

Expand eligibility for conditional cash transfers and scholarships (need- and merit-based) to girls in well-credentialed nonformal programs ...................................... 4

Collect data on and evaluate the impact of nonformal educational programs ................................ 4

Educational policies and programs to support girls in school during adolescence ............................5

Encourage the alignment of age with appropriate grade ............................................................. 5

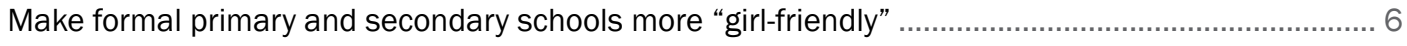

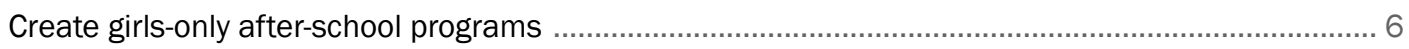

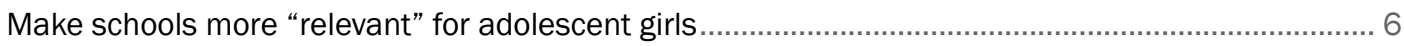

Establish an elite tier of teachers with additional training and compensation, who have demonstrated competencies in "relevant" subjects ................................................6 6

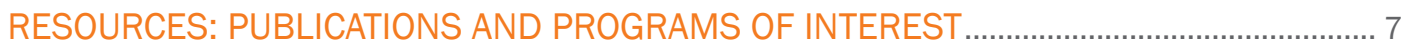

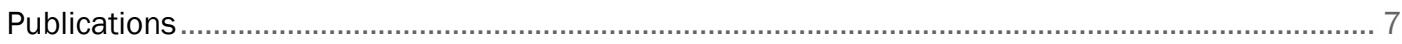

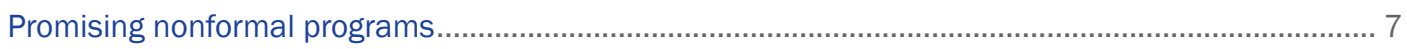

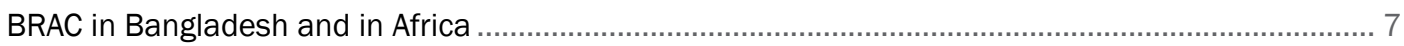

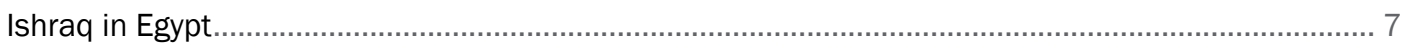

Norwegian Refugee Council's Youth Education Pack (YEP)

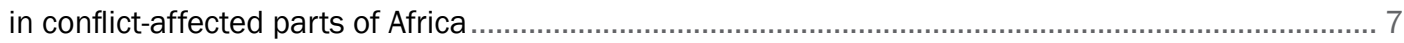

Promising programs in support of girl-friendly and relevant formal schooling ................................. 7

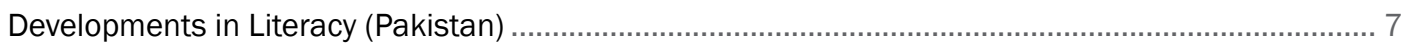

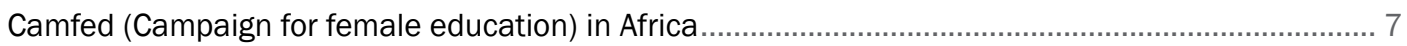

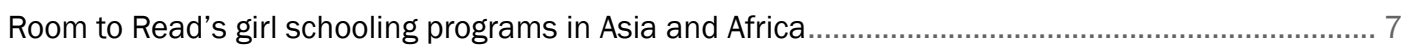

Forum for African Women Educationalists (FAWE), Gender responsive schools

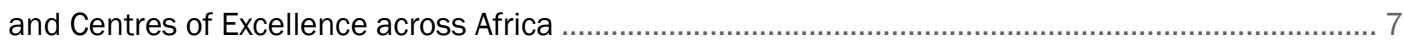

Japan Relief for Cambodia/American Assistance for Cambodia (JRfC/AAfC)

Girls be Ambitious (Cambodia). 


\section{BASIC KNOWLEDGE AND PREMISES}

Adolescence, which begins earlier for girls than boys, is a time of rapid growth and development physically, emotionally, and cognitively. For girls it is a stage of life during which education, when effectively provided, can be transformative. It is also a time when girls are most likely to drop out of school.

One of the most significant problems in most developing countries is the failure of education systems to realize their potential for empowering adolescent girls by providing economically productive skills. Education for girls during adolescence can protect them from the risks of premature sexual initiation, and allow them to postpone marriage and childbearing and to experience a childhood like that of boys, without the burden of excessive domestic work. A quality education for adolescent girls can also provide them with increased knowledge and greater skills for remunerative work and effective community engagement. Because girls become physically and sexually mature while they are still children (and therefore at risk), a quality education for them, whether in the formal or nonformal sector, should be simultaneously protective, girl-friendly, and empowering.

Schools have the potential to do more than they are currently doing to fully empower girls to translate learning and skill acquisition into remunerative employment, better health, and effective citizenship later in life. While the gender gap in educational enrollment and attainment is closing rapidly, the gender gap in labor force participation is not (Lloyd 2011).

Figure 1 contrasts the narrow gender gap in school attendance rates by age in four major regions with the widening gender gap in three of the four regions in labor force participa- tion as adolescents leave school and approach adulthood. It also shows the strikingly low levels of labor force participation by age in sub-Saharan Africa for both boys and girls. For schools to contribute to the longterm achievement of gender equity in society, they will need to benefit girls as much as, if not more than, boys.

A growing concern over the disadvantages faced by poor girls in developing countries in the past 15 years has led to a broad range of programmatic interventions designed for their benefit. Most of these programs, when developed outside the formal education system, have an educational component. Attention to the needs of adolescent girls in particular has emerged more recently. This attention has focused primarily on girls who either never went to school or dropped out prematurely, leaving them insufficiently prepared for adulthood and vulnerable to sexual risks as well as premature marriage and parenthood. Less attention has been directed to the needs of adolescent girls who remain in school, although this is beginning to change. These two populations of adolescent girlsthose who are currently enrolled and those no longer or never in schoolhave quite different needs.

This guide reviews what we know about the educational needs of adolescent girls in poor settings and highlights some of the most promising programmatic approaches. This paper draws heavily on the compendium of recent program approaches enumerated in New Lessons: The Power of Educating Adolescent Girls (Lloyd and Young 2009). New Lessons outlined an educational manifesto for girls detailing where they should be and the skills they should be acquiring at each stage of adolescence.
PROMISING

APPROACHES TO BE TESTED AND EXPANDED

There is a wide range of policies and programs designed to support adolescent girls' education, some of which seem particularly creative and promising. Unfortunately, many of these good ideas have not been evaluated and are not widely known. Below, we identify some of the most promising of these approaches targeting adolescent girls who are currently out of school and need further education and those who are enrolled in formal schools and need support to continue their education through adolescence. Where appropriate, we recommend that these approaches be tested on an experimental basis using randomization to establish proof of concept.

Nonformal educational programs for out-of-school adolescent girls Establish and strengthen pathways from nonformal to formal schooling; focus on younger girls

We have strong evidence of the impressive social and economic returns for girls of attending formal secondary school (Lloyd and Young 2009). This evidence suggests that nonformal programs should increasingly shift their attention to a younger population of out-of-school girls who still have the chance to reenter the formal system and make the transition to formal secondary school. Thus, it also suggests that nonformal education programs be upgraded, certified, and licensed and that pathways be established from nonformal to formal sectors where they do not currently exist.

Expand support for nonformal educational alternatives with the goal of providing marketable skills

Many NGOs and some governments have developed nonformal educational alternatives for adolescent girls 


\section{FIGURE 1 RATES OF SCHOOL ATTENDANCE AND LABOR FORCE}

PARTICIPATION AMONG ADOLESCENTS, BY REGION AND SEX

\section{Girls' transitions out of school are not mirrored by equivalent transitions into the labor force.}
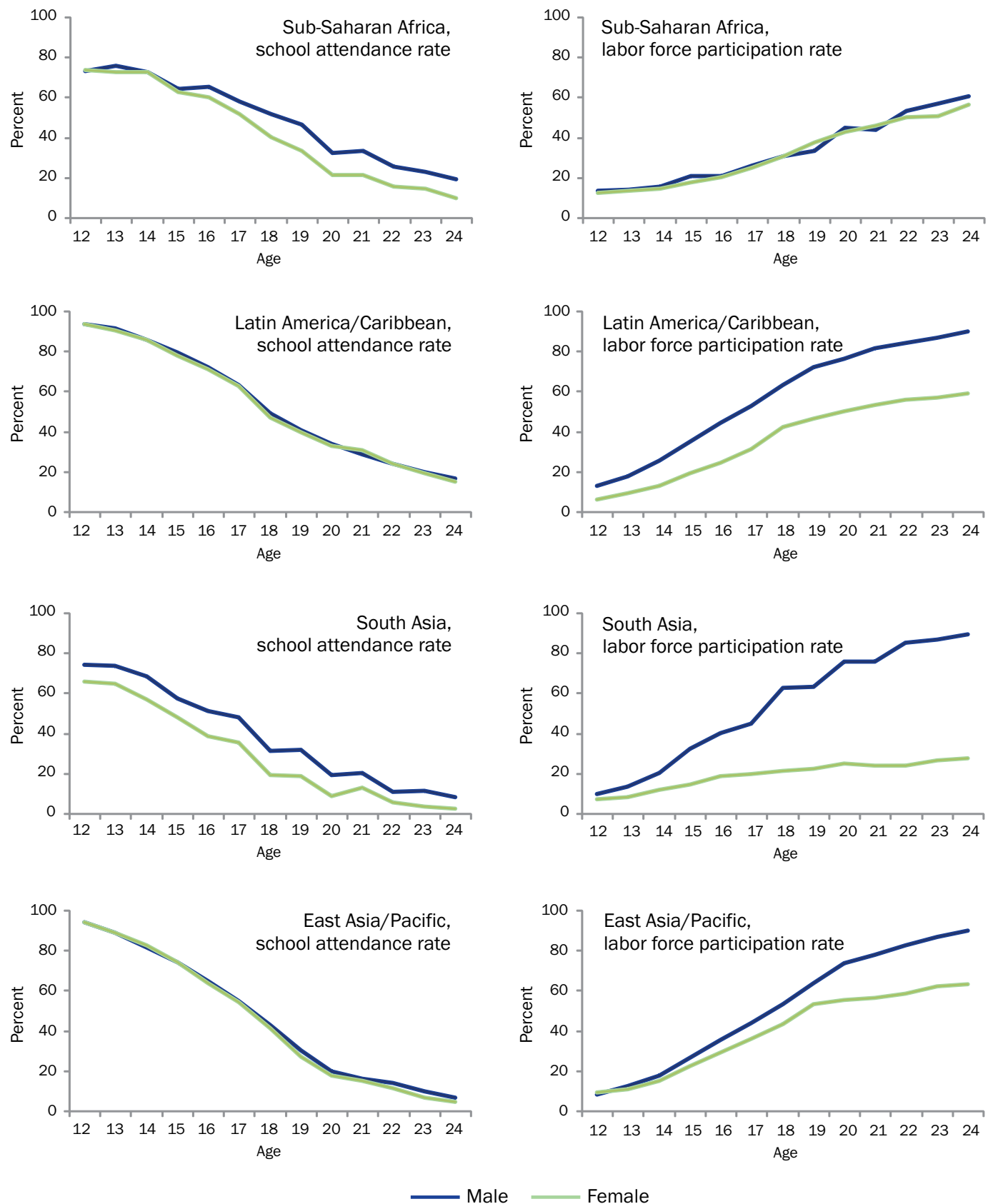

Source: Buvinic, Guzman, and Lloyd (2007) 
who have either missed out on school altogether or dropped out of formal schooling before becoming literate or completing primary school. The intent of these programs is to provide a fasttrack compensatory educational alternative by providing marketable skills, including literacy. The size of this population of girls increases with age and, in some of the poorest settings, includes more than 50 percent of adolescent girls. Figure 2 shows the size and composition (in terms of grades attained) of this group in a range of poor countries. For example, in Mali and Bangladesh, a majority of girls are out of school by age 15 . The overwhelming majority of these girls have not completed primary school, and many of them have not achieved functional literacy (Lloyd and Young 2009).

\section{Expand eligibility for conditional cash}

transfers and scholarships (need- and merit-based) to girls in well-credentialed nonformal programs

While some governments have integrated nonformal education within their larger education system, nonformal education in most countries is largely operated by NGOs outside the regular government system. Girls who have been left behind are likely to be particularly in need of financial assistance to support their transition back into the formal system. To date, most conditional cash transfer programs and scholarship programs for girls are targeted to the girls attending formal schooling. In places where nonformal educational alternatives are well developed, scholarships could be made available to girls, conditional on acceptance and satisfactory attendance in formal school. This will provide the neediest and most promising students with opportunities to reenter the formal system at either the primary or secondary level, depending on girls' academic knowledge and skills.

The availability of such programs could also help bring nonformal education out of the shadows so that its quality could be better regulated. Outcomes to be assessed would include learning and labor market outcomes. The experience of BRAC in Bangladesh provides an excellent model of the effective integration of the nonformal and the formal education systems.

\section{Collect data on and evaluate the impact of nonformal educational programs}

No data are currently available on the participation of adolescent girls in nonformal educational programs, nor have such programs been effectively evaluated for impact. A variety of ex-

\section{AN EDUCATIONAL MANIFESTO FOR ADOLESCENT GIRLS}

KNOWLEDGE AND SKILLS THAT GIRLS SHOULD BE ACQUIRING AT EACH STAGE OF ADOLESCENCE

\begin{tabular}{|c|c|c|}
\hline & WHERE EVERY GIRL SHOULD BE & $\begin{array}{l}\text { WHAT EVERY GIRL SHOULD BE } \\
\text { ACQUIRING }\end{array}$ \\
\hline $\begin{array}{l}\text { Early adolescence } \\
\text { Ages } 10-12\end{array}$ & $\begin{array}{l}\text { Formal primary school or } \\
\text { accelerated complementary } \\
\text { school }\end{array}$ & $\begin{array}{l}\text { Literacy, numeracy, critical thinking skills, } \\
\text { basic health knowledge, knowledge about } \\
\text { their communities and the world }\end{array}$ \\
\hline $\begin{array}{l}\text { Middle adolescence } \\
\text { Ages } 13-15\end{array}$ & $\begin{array}{l}\text { Post-primary formal school or } \\
\text { accelerated complementary } \\
\text { school }\end{array}$ & $\begin{array}{l}\text { Reading and writing fluency for lifelong } \\
\text { learning, critical thinking skills, fluency } \\
\text { in an internationally spoken language, } \\
\text { computer skills, proficiency in math/ } \\
\text { science, health and reproductive health } \\
\text { knowledge, financial literacy, skills for } \\
\text { social and civic participation, knowledge } \\
\text { about social systems and local and global } \\
\text { issues }\end{array}$ \\
\hline $\begin{array}{l}\text { Late adolescence } \\
\text { Ages } 16-19\end{array}$ & $\begin{array}{l}\text { Formal secondary school or } \\
\text { alternative nonformal education } \\
\text { with a vocational or livelihoods } \\
\text { focus }\end{array}$ & $\begin{array}{l}\text { Marketable skills, information-gathering } \\
\text { skills and habits for lifelong learning, } \\
\text { financial knowledge and skills }\end{array}$ \\
\hline
\end{tabular}

Source: Lloyd and Young (2009) 


\section{FIGURE 2 PERCENT OF GIRLS OUT OF SCHOOL, BY AGE, ACCORDING TO}

\section{HIGHEST GRADE COMPLETED}

The educational backgrounds of out-of-school adolescent girls vary substantially across countries.
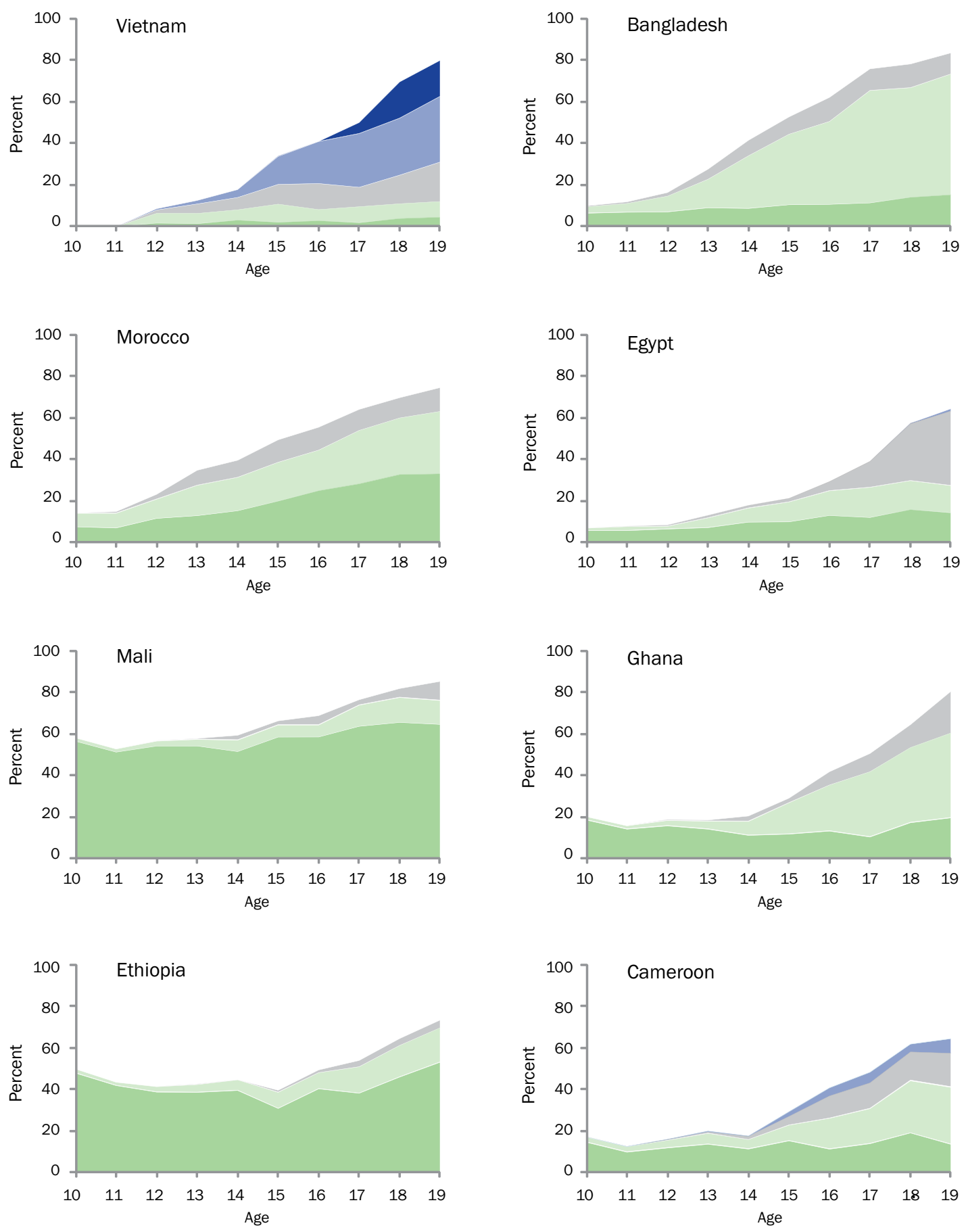

Never attended $\quad 1$ to 4

5,

7 to 9

10 plus 
perts suggest that enrollment in these programs may have become considerable in recent years (Lloyd and Young 2009). In most countries, the Ministry of Education does not manage these programs, and therefore the collection of information on their enrollment and impact does not fall within the scope of their national management information systems. Furthermore, alternative data collection systems, such as nationally representative sample surveys like DHS and MICS, have not yet adapted their questions about educational participation to identify nonformal educational participation in a mean-ingful way.

Educational policies and programs to support adolescent girls in school

Encourage the alignment of age with appropriate grade

The Millennium Development Goals targeting education (Goals 2 and 3) have focused on the completion of primary schooling for all children and the elimination of gender gaps in education at all levels. Much progress has been made toward these goal since 2000. The overwhelming majority of children in the world (including girls) are now attending school. A more meaningful and forward- looking goal for the international community to embrace at this point is the achievement of universal enrollment that is ageappropriate by grade. Being behind grade for age can be caused by delays in starting school and can contribute to girls leaving school before completing secondary school. The attainment of this more ambitious but critical goal would ensure that girls are well positioned to enter secondary school before the onset of puberty.

At a more practical level, it makes sense to pay greater attention to differences in outcomes between adolescent girls who attend classrooms with classmates of the same age and girls who attend classrooms with classmates of a wide range of ages. Indeed, it is not uncommon for 13-year-olds to find themselves in a classroom with 18-year-olds, particularly in sub-Saharan Africa (Lloyd 2010). We have evidence from South Africa that adolescent girls who are age-appropriate for their grade often experience sexual advances by older boys in the same classroom, with the result that they experience more detrimental reproductive health outcomes, including pregnancy, than other girls in the classroom who are the same age as the older boys (Marteleto, Lam, and Ranchhod 2008). This age diversity also contributes to the disappointing results of many school-based HIVprevention programs because sensitive subjects are much more difficult to teach in classrooms where some students have not yet reached puberty while others are already mature and sexually active. These observations strongly support the idea that adolescent girls might experience a more girlfriendly environment in school settings where consistent ages of entry have been enforced. In large schools (often in urban settings) that have a sufficient number of students for tracking by age within grade, a randomized pilot program could compare health and learning outcomes for adolescent girls in classrooms where all students are of a similar age with outcomes for girls in classrooms where there are students of diverse ages.

\section{Make formal primary and secondary} schools more "girl-friendly"

Many approaches to creating a girlfriendly environment in the classroom are currently in practice; some are known to be effective, some appear promising but have not been evaluated, and some are unlikely to improve girls' outcomes. Research suggest that:

- recruiting and training female teachers can improve outcomes for girls. However, program evaluations have not addressed the effectiveness of different ap- proaches to doing this in places where female teachers remain in the minority;

- mentoring, tutoring and peer support, and gender training for teachers appear to be promising approaches, but rigorous evaluations of these approaches need to be conducted.

- provision of girls-only toilets and the provision of sanitary supplies are unlikely to improve the enrollment and attendance of adolescent girls even though we know that girls welcome such amenities. A review of recent research studies provides no evidence that these interventions have any effect on rates of enrollment or dropout (Lloyd and Young 2009).

Create girls-only after-school programs

Even when adolescent girls are enrolled in formal school (whether in upper primary or secondary), they are typically expected to work longer hours on domestic tasks after school than their enrolled brothers (Lloyd, Grant, and Ritchie 2008). This finding suggests that adolescent girls would benefit even more than boys from the opportunity for some personal time after regular school hours and with other girls. After-school programs for girls could focus on developing life skills, including financial literacy and leadership skills. At the same time, opportunities could be provided for older girls to serve as mentors for younger girls. In this context, age diversity could be a potential benefit, if appropriately channeled, rather than a disadvantage.

Make schools more "relevant" for adolescent girls

Issues of educational relevance transcend gender. But, given what we know about young women's current disadvantages in the labor market, educational reforms that address the 
issues of relevance are likely to differentially benefit girls. For example:

- English fluency and computer skills: global shifts in labor demand are creating more opportunities for women in sectors such as services and tourism that often demand English fluency and computer skills. If girls are adequately prepared in school, they will be able to seize those opportunities.

- Financial literacy: life skills programs that give girls a more realistic sense of their futures, including the possibility of assuming financial responsibility for managing a household, provide a strong motivation for acquiring basic financial literacy.

Establish an elite tier of teachers with additional training and compensation, who have demonstrated competencies in "relevant" subjects

Secondary school curriculums and teacher training for the secondary level are not sufficiently attuned to today's global realities. While a growing number of girls enter secondary school, relatively few graduate, particularly in sub-Saharan Africa. Highly trained teachers would be the first step in the implementation of a "more relevant curriculum." Special inducements could be provided for young women to become elite teachers. Outcomes to be assessed would include specific learning competencies and labor market outcomes for both teachers and students.

\section{RESOURCES:}

PUBLICATIONS AND PROGRAMS OF INTEREST

\section{Publications}

Buvinic, M., J.C., Guzman, and C.B. Lloyd. 2007 "Gender shapes adolescence," Development Outreach, June: 12-15. World Bank Institute.
Lloyd, Cynthia B. 2011. "Translating education gains into labor force gains for young women: alternative education strategies," Background paper for EFA Global Monitoring Report. 2011. Paris: UNESCO.

Lloyd, Cynthia B. 2010. "The role of schools in supporting and promoting sexual and reproductive health among adolescents in developing countries," in S. Malarcher (ed.), Social Determinants of Sexual and Reproductive Health: Informing Programmes and Future Research. Geneva: World Health Organization, pp. 113-131.

Lloyd, Cynthia B. with Juliet Young. 2009. New Lessons: The Power of Educating Adolescent Girls-A Girls Count Report on Adolescent Girls. New York: Population Council.

Lloyd, Cynthia B., Monica J. Grant, and Amanda Ritchie. 2008. "Gender differences in time use among adolescents in developing countries: Implications of rising school enrollment rates," Journal of Research on Adolescence 18(1): 99-120.

Marteleto, Leticia, David Lam, and Vimal Ranchhod. 2008. "Sexual behavior, pregnancy and schooling among young people in urban South Africa," Studies in Family Planning 39(4): 351-368.

\section{Promising nonformal programs BRAC in Bangladesh and in Africa}

BRAC is a global pioneer in education, currently operating the largest private, secular education system in the world. BRAC's nonformal primary education program is a high-impact, low-cost model for teaching children who had never enrolled, or had dropped out of primary school. To date, nearly 5 million children, mostly girls, have graduated from BRAC schools and an overwhelming majority of them have gone into the public school system, performing, on average, better than their mainstream peers. BRAC's work in education has reached 10 million children across the globe. For more information, visit the BRAC website at: http://brac.net/content/what-we-doeducation
Ishraq in Egypt

In rural Upper Egypt, the Population Council's Ishraq project brings out-ofschool adolescent girls into safe learning spaces. The program improves functional and financial literacy and life skills, and allows girls to play sports, an opportunity not usually available to them. The project components work together to provide girls with new and valued skills and to increase their self-esteem and confidence. For more information, contact Population Council senior program officer Nadia Zibani at nzibani@popcouncil.org, or visit the project's website, http:// www.popcouncil.org/projects/40_ IshraqSafeSpacesGirls.asp

Norwegian Refugee Council's Youth Education Pack (YEP) in conflictaffected parts of Africa

YEP gives education opportunities to conflict-affected youth, who, as a result of displacement and lack of opportunities, have missed out on schooling and skills development. YEP is a one-year, full-time nonformal education and livelihood program with three equally important components; literacy/numeracy, life skills, and basic vocational skills training. Priority is given to young single mothers, youth heads of households, and those with the poorest educational background. For more information, visit the Norwegian Refugee Council's website, http://www.nrc.no/?did=9534911

Promising programs in support of girl-friendly and relevant formal schooling

Developments in Literacy (Pakistan)

Developments in Literacy (DIL) educates and empowers poor students, especially girls, by operating studentcentered model schools. The organization also provides high-quality professional development to teachers and principals across Pakistan. For more information, visit the organization's website, http://www.dil.org 
Camfed (Campaign for Female Education) in Africa

Camfed focuses on rural areas of Africa, where poverty is widespread and girls and young women are excluded from education and the opportunities education affords. Camfed works to support girls so that they can attend and succeed at primary and secondary school, and progress into young adulthood with opportunities that include professional training, higher education, and job creation. For more information, visit the organization's website, http:// us.camfed.org

Room to Read's girl schooling programs in Asia and Africa

Room to Read focuses on literacy and gender equality in education. The organization works in collaboration with communities and local governments across Asia and Africa to develop literacy skills and a habit of reading among primary school children, and to help girls complete secondary school with the life skills they need to succeed in school and beyond. For more information, visit the organization's website, http://www.roomtoread.org/ page.aspx?pid=284

Forum for African Women Educationalists (FAWE), Gender-responsive schools and Centres of Excellence across Africa

FAWE has developed the Centre of Excellence (COE) model through which ordinary schools are transformed into gender-responsive schools that offer quality education and pay attention to the physical, academic, and social dimensions of both girls' and boys' education. For more information, visit the organization's website, http:// www.fawe.org/activities/interventions/ COEs/index.php

Japan Relief for Cambodia/American Assistance for Cambodia (JRfC/AAfC) Girls be Ambitious (Cambodia)

The objective of the Girls be Ambitious program is to prevent the trafficking of Cambodian girls and women for sexual and labor exploitation through an incentive program for girls from poor homes to stay in school and receive additional vocational training that will provide employment alternatives, income generation, and social and political empowerment. For more information, visit the organization's website, http:// www.camnet.com.kh/Girls-Ambitious . 



\section{(1) Population Council}

The Population Council confronts critical health and development issues-from stopping the spread of HIV to improving reproductive health and ensuring that young people lead full and productive lives. Through biomedical, social science, and public health research in 50 countries, the Council works with our partners to deliver solutions that lead to more effective policies, programs, and technologies that improve lives around the world. Established in 1952 and headquartered in New York, the Council is a nongovernmental, nonprofit organization governed by an international board of trustees.

www.popcouncil.org 